\title{
Cardiac Connexin-43 and PKC Signaling in Rats With Altered Thyroid Status Without and With Omega-3 Fatty Acids Intake
}

\author{
B. SZEIFFOVÁ BAČOVÁ ${ }^{1}$, T. EGAN BEŇOVÁ ${ }^{1}$, C. VICZENCZOVÁ ${ }^{1}$, T. SOUKUP ${ }^{2}$, \\ H. RAUCHOVÁ ${ }^{2}$, S. PAVELKA ${ }^{2}$, V. KNEZL ${ }^{3}$, M. BARANČÍK ${ }^{1}$, N. TRIBULOVÁ ${ }^{1}$ \\ ${ }^{1}$ Institute for Heart Research, Slovak Academy of Sciences, Bratislava, Slovak Republic, ${ }^{2}$ Institute \\ of Physiology of the Czech Academy of Sciences, Prague, Czech Republic, ${ }^{3}$ Institute of \\ Experimental Pharmacology and Toxicology, Slovak Academy of Sciences, Bratislava, Slovak \\ Republic
}

Received June 25, 2016

Accepted July 8, 2016

\section{Summary}

Thyroid hormones are powerful modulators of heart function and susceptibility to arrhythmias via both genomic and non-genomic actions. We aimed to explore expression of electrical coupling protein connexin-43 (Cx43) in the heart of rats with altered thyroid status and impact of omega- 3 polyunsaturated fatty acids (omega-3) supplementation. Adult male Lewis rats were divided into following six groups: euthyroid controls, hyperthyroid (treated with $\mathrm{T}_{3}$ ) and hypothyroid (treated with methimazol) with or without six-weeks lasting supplementation with omega-3 $(20 \mathrm{mg} / 100 \mathrm{~g} / \mathrm{day})$. Left and right ventricles, septum and atria were used for immunoblotting of $\mathrm{C} \times 43$ and protein kinase $\mathrm{C}$ (PKC). Total expression of $\mathrm{Cx} 43$ and its phosphorylated forms were significantly increased in all heart regions of hypothyroid rats compared to euthyroid controls. In contrast, the total levels of Cx43 and its functional phosphorylated forms were decreased in atria and left ventricle of hyperthyroid rats. In parallel, the expression of PKC epsilon that phosphorylates Cx43, at serine 368, was increased in hypothyroid but decreased in hyperthyroid rat hearts. Omega-3 intake did not significantly affect either $\mathrm{C} \times 43$ or PKC epsilon alterations. In conclusion, there is an inverse relationship between expression of cardiac $\mathrm{C} \times 43$ and the levels of circulating thyroid hormones. It appears that increased propensity of hyperthyroid while decreased of hypothyroid individuals to malignant arrhythmias may be in part attributed to the changes in myocardial $\mathrm{Cx} 43$.

\section{Key words}

Thyroid hormones - Cardiac arrhythmias - Connexin-43 • Omega-3 polyunsaturated fatty acids

\section{Corresponding author}

B. Szeiffova Bacova, Institute for Heart Research, Slovak Academy of Sciences, Dúbravská cesta 9, POBox 104, 84005 Bratislava, Slovak Republic. E-mail: barbara.bacova@savba.sk

\section{Introduction}

Thyroid hormones (TH) are powerful modulators of heart function. The cellular action of TH is largely derived from its long-term effects resulting in thyrotoxicosis and hypothyroidism. Overt hyperthyroidism is a pathological syndrome in which tissue is exposed to excessive amounts of circulating $\mathrm{TH}$, while its deficiency is associated with overt hypothyroidism. There is prevalence of overt thyroid disease with aging and subclinical thyroid dysfunction in young adults. Both, hyperthyroidism and hypothyroidism are associated with oxidative stress in animals as well as in humans that is deleterious to the heart (Mancini et al. 2016). Clinical studies indicate that excess of $\mathrm{TH}$ increases a risk for atrial fibrillation and ventricular arrhythmias while hypothyroidism can result in atherosclerosis and heart failure (Gao et al. 2016). On the other hand, cardioprotective role of $\mathrm{TH}$ in the complexity of post-ischemic heart disease has been highlighted recently (Pingitore et al. 2016, Rajagopalan et al. 2016, Pantos et al. 2011, Zhang et al. 2014).

Although prominent effects of $\mathrm{TH}$ are thought to be mediated by the nuclear thyroid receptors, there is an increasing evidence for their nongenomic (non-nuclear) 
action whereby both can interact (Iordanidou et al. 2010, Pantos et al. 2011, Portman 2008, Zinman et al. 2006). Acute actions of $\mathrm{TH}$ are thought to be mediated by direct binding to the target proteins or influencing intracellular signaling (Rybin and Steinberg 1996, Iordanidou et al. 2010) and subsequent regulation of gating of the ion channels (e.g. via PKA, PKC phosphorylation). Of note, numerous nongenomic mechanisms involve phosphorylation-dephosphorylation of substrate proteins (Portman 2008).

Both, genomic and nongenomic actions of $\mathrm{TH}$ affect cardiac electrophysiology and $\mathrm{Ca}^{2+}$ handling due to effects on potassium, calcium and RyR channels and SERCA2a. Evidence suggests that these actions as well as modulation of electrical coupling mediated by intercellular connexin-43 (Cx43) channels may be implicated in proand antiarrhythmic effects of TH (Purtel et al. 2010, Tribulova et al. 2010). Indeed, as previously has been shown, hyperthyroid rat heart is prone to lethal ventricular fibrillation (VF) whereby intercellular Cx43 channels are likely involved (Lin et al. 2008). On the other hand, an increase of circulating $\mathrm{TH}$ can prevent triggered activity, ventricular premature beats and tachyarrhythmia most likely due to prevention of $\mathrm{Ca}^{2+}$ overload (Zinman et al. 2006, Tribulova et al. 2004a, 2010).

Considering a crucial role of myocardial $\mathrm{Cx} 43$ channels in electrical and molecular signal propagation between cardiomyocytes for synchronized heart function (Salameh and Dhein 2005), it would be interesting to investigate $\mathrm{Cx} 43$ response to altered thyroid status in all regions of the heart because such data are missing. We aimed to explore $\mathrm{Cx} 43$ expression in atria, right and left ventricle as well as septum of hyper- and hypothyroid rats. Moreover, we examined protein kinase $\mathrm{C}$ signaling that is modulated by TH (Rybin and Steinberg 1996) and may have impact on functional phosphorylated state of Cx43 in these conditions. Finally, taken into account cardioprotective and antiarrhythmic effects of omega-3 polyunsaturated fatty acids intake in humans as well as animals (Soukup 2014), we thought to explore their effects on cardiac $\mathrm{Cx} 43$ and PKC signaling in altered thyroid status.

\section{Material and Methods}

The experiments were conducted on male inbred Lewis rats $(n=36)$ from the authorized rat-breeding unit of the Institute of Physiology of the Czech Academy of Sciences, Prague, Czech Republic. The animals were housed at $23 \pm 1{ }^{\circ} \mathrm{C}$ and at $12 / 12 \mathrm{~h}$ light-dark cycle periods with ad libitum access to tap water and a conventional laboratory chow. The maintenance of rats was in compliance with the EU Council Directive 86/609EEC and the investigation was approved by the Expert Committee of the Institute of Physiology of the Czech Academy of Sciences, Prague, Czech Republic. At the age of one month, rats were randomly divided into following groups: euthyroid, hyperthyroid and hypothyroid. The hyperthyroid (hT) status was induced by intraperitoneal injection of $\mathrm{T}_{3} \quad(0.15 \mathrm{mg} / \mathrm{kg}$ body weight) three times a week and maintained until the end of experiment. Thyroid hormone deficient (dT) status was induced with a $0.05 \%$ solution of methimazole in drinking water and maintained until the end of experiment. The euthyroid rats (nT) with normal levels of thyroid hormones were age-matched experimental animals. Pure omega-3 (docosahexaenoic acid [DHA] + eicosapentaenoic acid [EPA] ethylesters, Pronova BioPharma, Norway), were administered via gavages ( $200 \mathrm{mg} / \mathrm{kg}$ body weight/day) to a half of the rats in each experimental group for six weeks.

At the end of experiment, the animals were euthanized with Narketan (Ketamine, $100 \mathrm{mg} / \mathrm{kg}$ body weight, i.p.) followed by myorelaxant Xylapan (Xylazine, $10 \mathrm{mg} / \mathrm{kg}$ body weight). The chest was opened and heart from each rat was quickly excised and placed into ice-cold saline to stop beating. Heart weight was registered and the heart was quickly separated into left ventricle (LV), right ventricle (RV), septum (S) and atria (A) followed by freezing in liquid nitrogen. Tissue and blood plasma samples were stored at $-80^{\circ} \mathrm{C}$. Fasting blood glucose of the animals was measured using the easy-gluco-system (Infopia Co. Ltd, Anyang, South Korea) two days before the end of the experiment. Serum levels of total triiodothyronine $\left(\mathrm{tT}_{3}\right)$ and total thyroxine $\left(\mathrm{tT}_{4}\right)$ were assayed radioimmunologically using commercial RIA kits (Immunotech-Beckman Colter Co., Prague, Czech Republic). Biometrical parameters of experimental rats were registered as well.

Samples from LV, RV, S and A were used for immunoblotting of $\mathrm{Cx} 43$, protein kinase $\mathrm{C}$ epsilon (PKCE) and $\mathrm{PKC}$ delta $(\mathrm{PKC} \delta)$ as described previously (Bacova et al. 2012). In brief, cardiac tissue was powdered and solubilized in SB20 solution (20\% SDS, $10 \mathrm{mmol} / 1$ EDTA, 100 mmol/l Tris, pH 6.8) by sonicator (UP 100H; Hielscher, Germany). An equal amount of total protein in each sample was separated in $10 \%$ SDS-PAGE and transferred electrophoretically to a nitrocellulose 
membrane. For $\mathrm{Cx} 43$ determination, the nitrocellulose membrane was incubated with primary rabbit polyclonal antibody (anti-Connexin 43 C 6219; Sigma-Aldrich, diluted 1:2000). This antibody recognizes an epitope in the extreme C-terminal tail of $\mathrm{Cx} 43$ and can recognize all phosphovariants of $\mathrm{Cx} 43$, including serine 368. For $\mathrm{PKC} \varepsilon$ and $\mathrm{PKC} \delta$ determination, the nitrocellulose membrane was incubated with primary rabbit polyclonal antibodies (PKCE Antibody, C-15: sc-214, Santa Cruz Biotechnology, Inc., PKC $\delta$ Antibody, C-17: sc-213, Santa Cruz Biotechnology, Inc.,) diluted $1: 100$, overnight at $4{ }^{\circ} \mathrm{C}$, followed by further incubation for $1 \mathrm{~h}$ at room temperature with a secondary donkey antibody (peroxidase-labeled anti-rabbit, 1:2000, Amersham Biosciences). Bound antibodies were detected by the ECL method. The optical density of individual bands was analyzed by Carestream Molecular Imaging Software (USA) program and normalized to glyceraldehyde-3-phosphate dehydrogenase (GAPDH) as an internal control.

Due to limitation of cardiac chamber-related tissue samples only left ventricle was used for determination of matrix metalloproteinase (MMP-2) activity by zymography. The samples were mixed in a ratio of 1:1 with non-reducing Laemmli's buffer and subjected to electrophoresis on $10 \%$ SDS-polyacrylamide gels co-polymerized with gelatin (final concentration of $2 \mathrm{~g} / \mathrm{l}$ ). After electrophoresis, gels were washed twice for $20 \mathrm{~min}$ each with $50 \mathrm{mmol} / 1$ Tris- $\mathrm{HCl}$ buffer ( $\mathrm{pH} 7.4$ ), containing $2.5 \%$ Triton $\mathrm{X}-100$, at $25^{\circ} \mathrm{C}$. After washing, the gels were incubated overnight at $37^{\circ} \mathrm{C}$ in substrate (developing) buffer containing $50 \mathrm{mmol} / 1$ Tris-HCl buffer (pH 7.4), $10 \mathrm{mmol} / 1 \mathrm{CaCl}_{2}$ and $1.25 \%$ Triton $\mathrm{X}-100$. After this incubation, the gels were stained with $1 \%$ Coomassie Brilliant Blue G-250 dissolved in an aqueous solution containing $10 \%$ acetic acid and $40 \%$ methanol and then destained with an aqueous solution containing $10 \%$ acetic acid and $40 \%$ methanol. Gelatinolytic activities of MMP-2 were detected as transparent bands against a dark blue background (Barancik et al. 2012).

\section{Statistical analysis}

Statistical differences between thyroid status and effect of omega-3 were evaluated using one way ANOVA and Tukey's multiple comparison test. Differences of the protein expression depending on the respective region of the heart between two groups (LV vs. RV, LV vs. S, LV vs. A) were evaluated using T-test. Data were expressed as mean $\pm \mathrm{SD} ; \mathrm{P}<0.05$ was considered to be statistically significant.

\section{Results}

\section{Biometric and diagnostic parameters}

General registered characteristics of experimental rats are summarized in Table 1. There was a significant increase of blood serum $\mathrm{tT}_{3}$ but suppressed $\mathrm{tT}_{4}$ in hyperthyroid animals compared to euthyroid rats. In contrast, significant decrease of both $\mathrm{tT}_{3}$ and $\mathrm{tT}_{4}$ was registered in hypothyroid rats. Omega- 3 intake resulted in mild elevation of $\mathrm{tT}_{3}$ and $\mathrm{tT}_{4}$ in hyperthyroid as well as hypothyroid rats. Fasting blood glucose was significantly elevated in hyperthyroid but not in hypothyroid rats and not affected by omega-3 supplementation. There were no changes in body weight among the groups regardless the treatments. Comparing to euthyroid status there was a significant increase in absolute heart weigh in hyperthyroid rats while decrease in hypothyroid animals. The heart to body weight ratio was significantly increased in hyperthyroid rats only.

Table 1. General characteristics of the rats with altered thyroid status without and with omega fatty acids intake.

\begin{tabular}{lcccccc}
\hline & nT & nTo & hT & hTo & dT & dTo \\
\hline$t T_{3}(\mathrm{nmol} / \mathrm{l})$ & $1.0 \pm 0.1$ & $0.9 \pm 0.2$ & $5.6 \pm 1.7^{*}$ & $7.8 \pm 2.0$ & $0.3 \pm 0.1^{*}$ & $0.5 \pm 0.1 \#$ \\
$t T_{4}(\mathrm{nmol} / \mathrm{l})$ & $84 \pm 5$ & $98 \pm 7$ & $4.8 \pm 1.7^{*}$ & $6.1 \pm 2.4$ & $4.1 \pm 2.5^{*}$ & $5.9 \pm 2.0$ \\
$B G(\mathrm{mg} / \mathrm{dl})$ & $3.7 \pm 0.4$ & $4.0 \pm 0.3$ & $5 \pm 0.6^{*}$ & $4.9 \pm 0.4$ & $4.4 \pm 0.4$ & $4.1 \pm 0.4$ \\
$B W(g)$ & $321 \pm 40$ & $348 \pm 27$ & $303 \pm 52$ & $303 \pm 23$ & $285 \pm 60$ & $279 \pm 60$ \\
$H W(g)$ & $0.9 \pm 0.1$ & $0.9 \pm 0.1$ & $1.4 \pm 0.1^{*}$ & $1.3 \pm 0.1$ & $0.7 \pm 0.1^{*}$ & $0.7 \pm 0.1$ \\
$H W / B W(\mathrm{mg} / \mathrm{g})$ & $2.9 \pm 0.4$ & $2.8 \pm 0.3$ & $4.6 \pm 0.6^{*}$ & $4.2 \pm 0.2$ & $2.4 \pm 0.2$ & $2.5 \pm 0.2$ \\
\hline
\end{tabular}

$\mathrm{tT}_{3}$ - total triiodothyronine, $\mathrm{tT}_{4}$ - total thyroxine, $\mathrm{BG}$ - blood glucose, $\mathrm{BW}$ - body weight, $\mathrm{HW}$ - heart weight, $\mathrm{nT}$ - euthyroid control rats $(n=6)$, nTo - nT rats treated with omega-3 fatty acids (omega-3) $(n=6)$, dT - hypothyroid rats $(n=6)$, dTo - dT rats treated with omega-3 $(n=6)$, hT - hyperthyroid rats $(n=6)$, hTo - hT rats treated with omega-3 $(n=6)$. Data presented as mean $\pm S D, * P<0.05$ versus $\mathrm{nT}, \# \mathrm{P}<0.05$ untreated versus treated with omega-3. 


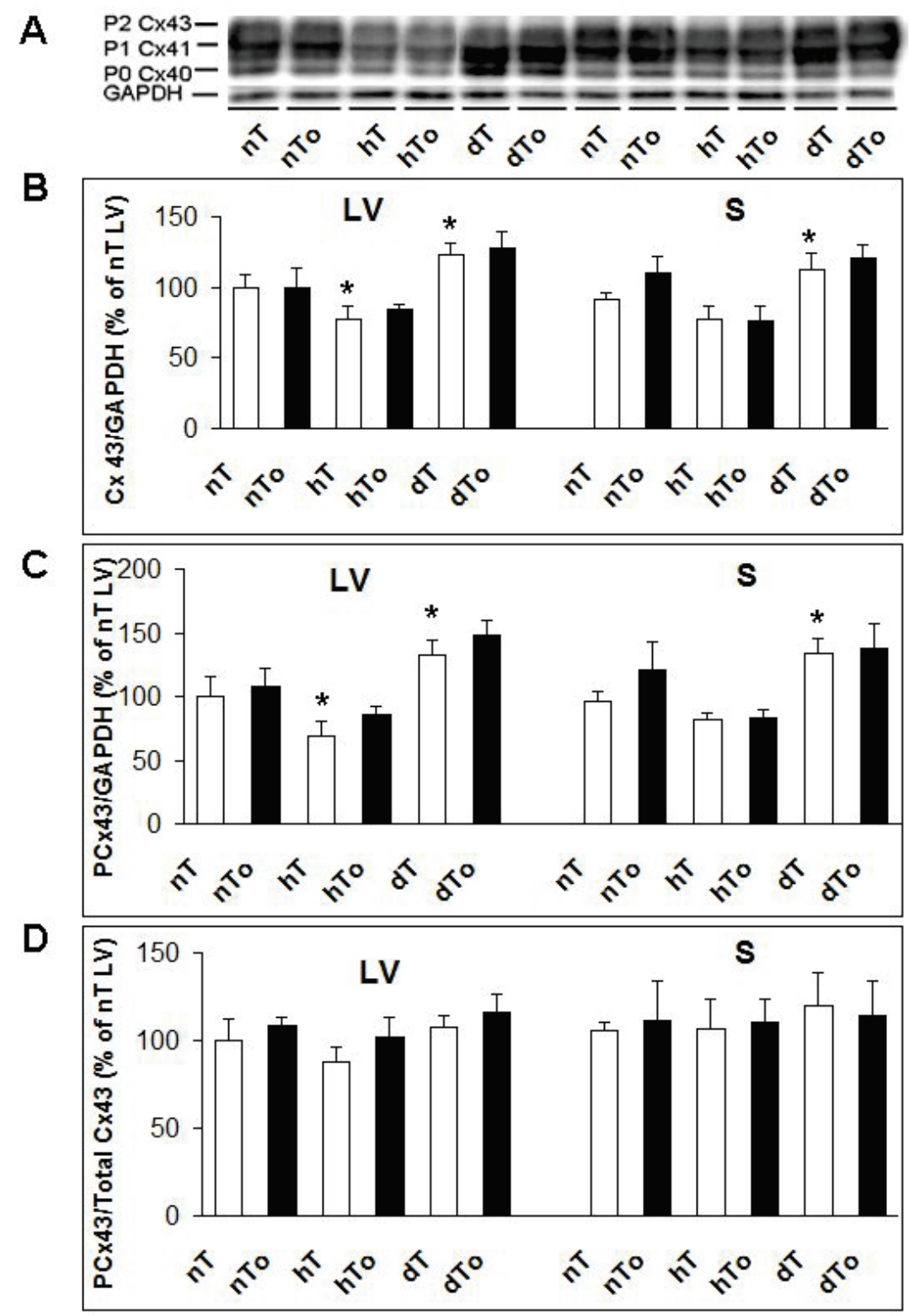

Fig. 1. Expression of myocardial total connexin-43 (Cx43) protein (AB), its phosphorylated forms (PCx43) (AC) and the ratio of PCx43 to total Cx43 (D) normalized to glyceraldehyde-3-phosphate dehydrogenase (GAPDH) levels in left ventricle (LV) and septum (S) of rats with altered thyroid status. nT - euthyroid control rats $(n=6), n T o-n T$ rats treated with omega-3 fatty acids (omega-3) $(n=6), d T-$ hypothyroid rats $(n=6)$, dTo - dT rats treated with omega-3 $3(n=6)$, hT - hyperthyroid rats $(n=6)$, hTo - hT rats treated with omega-3 $(n=6)$. Data presented as mean $\pm S D, * P<0.05$ versus $n T$ of $L V$ or $S$.

Myocardial connexin-43 protein expression and its phosphorylated status

Obtained findings presented in graphs demonstrate changes attributed to respective thyroid status as well as chamber-related differences comparing to the left ventricle.

Compared to euthyroid controls, myocardial expression of total $\mathrm{Cx} 43$ protein was significantly decreased in hyperthyroid rat heart by $\sim 25 \%$ in $\mathrm{LV}$ (Figs $1 \mathrm{AB}, 2 \mathrm{AB}$ and $3 \mathrm{AB}$ ) and by $18 \%$ in $\mathrm{A}$ (Fig. 2AB) but not changed in $\mathrm{S}$ and $\mathrm{RV}$ (Fig. 1AB, Fig. $3 \mathrm{AB}$ ). In parallel, phosphorylated forms of $\mathrm{Cx} 43$ were reduced by $\sim 28 \%$ in LV (Figs $1 \mathrm{AC}, 2 \mathrm{AC}$ and $3 \mathrm{AC}$ ) and by $23 \%$ in A (Fig. 2AC) but not changed in S (Fig. 1AC) and RV (Fig. 3AC). There was no difference in the ratio of phosphorylated forms of $\mathrm{Cx} 43$ to total $\mathrm{Cx} 43$ protein expression among the experimental groups (Figs 1D, 2D and 3D). Omega-3 intake did not affect either total or phosphorylated forms of $\mathrm{Cx} 43$ in hyperthyroid rats (Figs 1, 2 and 3) but increased by $28 \%$ total $\mathrm{Cx} 43$ expression in intact rat RV (Fig. 3AB).

On the contrary to hyperthyroidism induced down-regulation of cardiac $\mathrm{Cx} 43$, a significant increase of total $\mathrm{Cx} 43$ protein expression has been found by $\sim 28 \%$ in $\mathrm{LV}$ (Fig. $1 \mathrm{AB}, 2 \mathrm{AB}, 3 \mathrm{AB}$ ), by $21 \%$ in $\mathrm{S}$ (Fig. $1 \mathrm{AB}$ ), by $35 \%$ in $\mathrm{RV}$ (Fig. $3 \mathrm{AB}$ ) and by $26 \%$ in A (Fig. 2AB). It was accompanied by significant enhancement of phosphorylated forms of $\mathrm{Cx} 43$ expression as documented in Figure $1 \mathrm{AC}$ (by $33 \%$ in LV, by $37 \%$ in S), Figure $2 \mathrm{AC}$ (by $26 \%$ in LV, by $42 \%$ in A) and Figure $3 \mathrm{AC}$ (by $29 \%$ in LV, by $24 \%$ in RV). There was no difference in the ratio of phosphorylated forms of $\mathrm{Cx} 43$ to total $\mathrm{Cx} 43$ protein (Figs 1D, 2D and 3D). Omega-3 intake did not change the expression of 


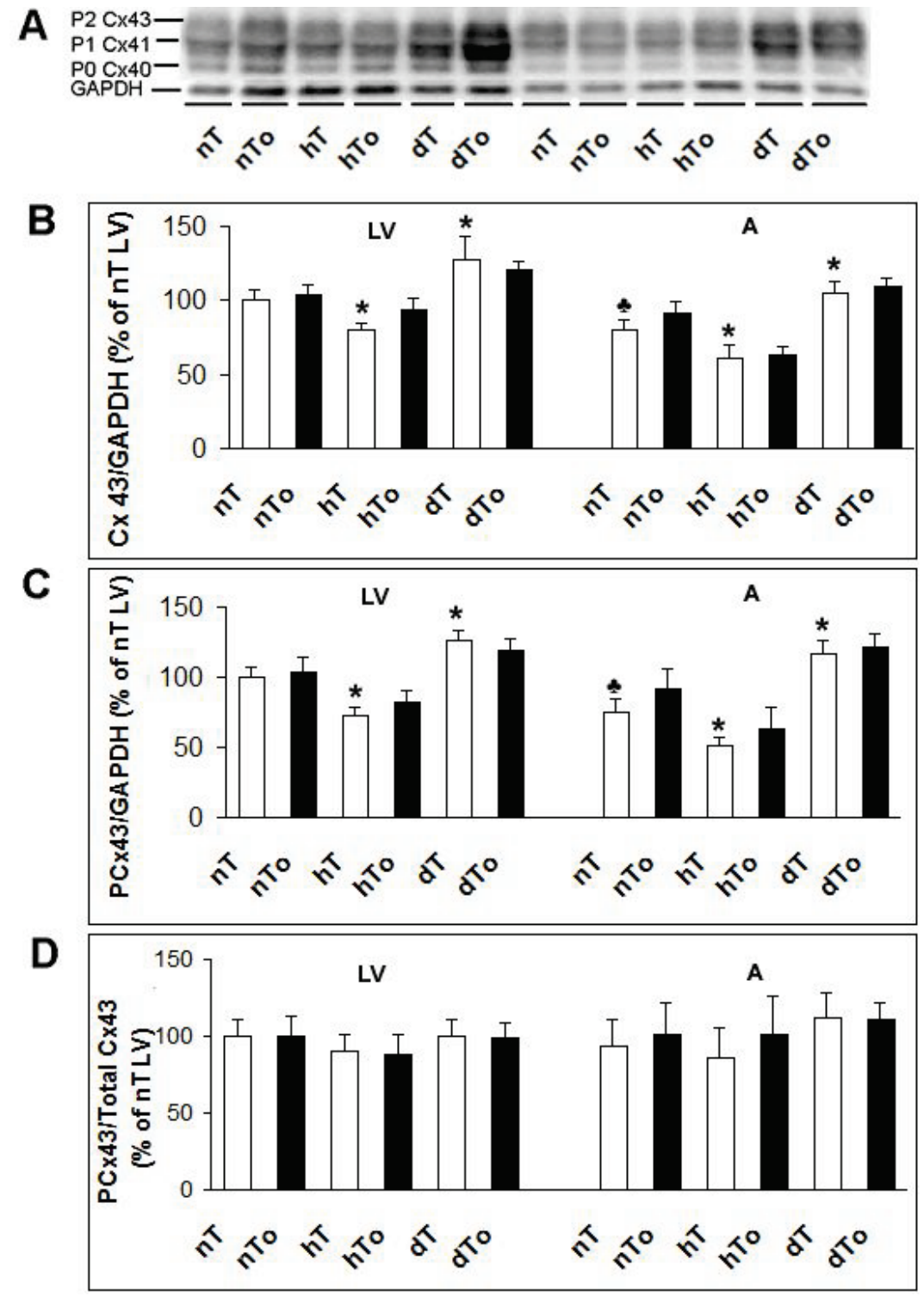

Fig. 2. Expression of myocardial total connexin-43 (Cx43) protein (AB), its phosphorylated forms (PCx43) (AC) and the ratio of PCx43 to total Cx43 (D) normalized to glyceraldehyde-3-phosphate dehydrogenase (GAPDH) levels in left ventricle (LV) and atrium (A) of rats with altered thyroid status. nT euthyroid control rats $(n=6)$, nTo - nT rats treated with omega- 3 fatty acids (omega-3) $(n=6), d T-$ hypothyroid rats $(n=6), d T o-d T$ rats treated with omega-3 $(n=6)$, hT hyperthyroid rats $(n=6), h T o-h T$ rats treated with omega-3 $(n=6)$. Data presented as mean $\pm \mathrm{SD}, * \mathrm{P}<0.05$ versus $\mathrm{nT}$ of $\mathrm{LV}$ or $\mathrm{A}$, - P<0.05 nT of the LV versus nT of the A. either total or phosphorylated forms of $\mathrm{Cx} 43$ in hypothyroid rat heart (Figs 1, 2 and 3).

Besides changes of myocardial $\mathrm{Cx} 43$ in response to hyperthyroidisms and hypothyroidism there was $19 \%$ lower atrial $\mathrm{Cx} 43$ expression comparing to ventricular (Fig. 2) regardless the thyroid status.

\section{Myocardial PKCE and PKC $\delta$ protein expression}

Obtained findings presented in graphs demonstrate changes attributed to respective thyroid status as well as chamber-related differences comparing to the left ventricle.

Protein expression of $\mathrm{PKC} \varepsilon$ was significantly decreased by $\sim 39 \%$ in LV, by $32 \%$ in RV, by $43 \%$ in $\mathrm{S}$ and by $24 \%$ in A of hyperthyroid rats. On the contrary, it was increased by $\sim 39 \%$ in LV, by $33 \%$ in RV, by $66 \%$ in $\mathrm{S}$ and by $25 \%$ in $\mathrm{A}$ of hypothyroid rats. Omega-3 intake did not affect alterations in $\mathrm{PKC} \varepsilon$ expression induced by altered thyroid status. Findings are summarized in Figure 4. Results also showed that myocardial expression of PKCE is highest in $\mathrm{LV}$ of euthyroid rat when comparing to other examined regions.

Protein expression of $\mathrm{PKC} \delta$ was dramatically increased by $\sim 156 \%$ in $\mathrm{LV}$, by $90 \%$ in RV as well as by $96 \%$ in S and by $94 \%$ in A of hyperthyroid rats (Fig. 5). The expression of PKC $\delta$ was significantly increased by $\sim 135 \%$ in LV of hypothyroid rats. Omega-3 intake did not affect thyroid status related alterations in $\mathrm{PKC} \delta$ expression (Fig. 5). Results also showed that myocardial expression of PKC $\delta$ is the same in all examined heart regions of euthyroid rats. 


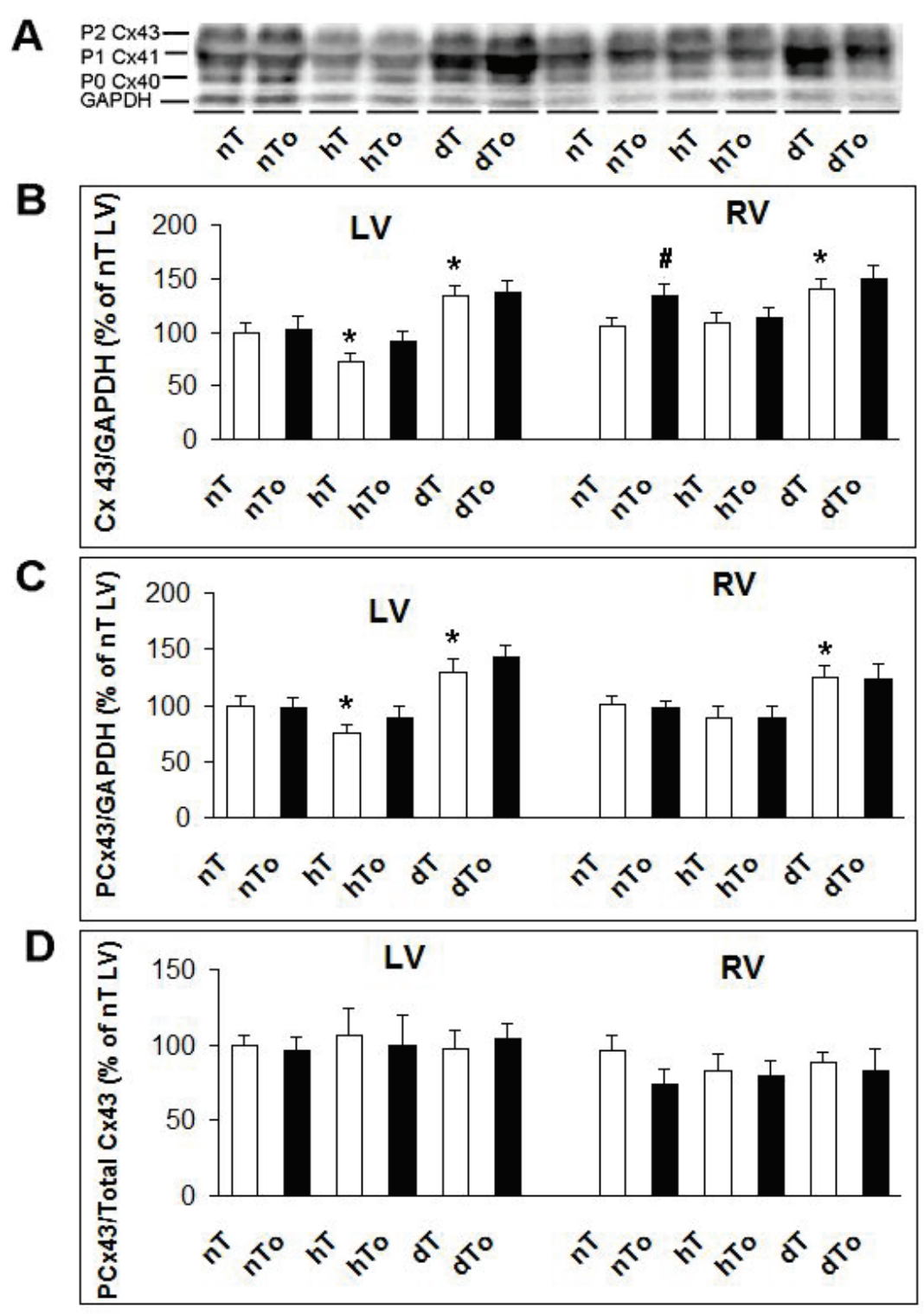

Fig. 3. Expression of myocardial total connexin-43 (Cx43) protein (AB), its phosphorylated forms (PCx43) (AC) and the ratio of PCx43 to total Cx43 (D) normalized to glyceraldehyde-3-phosphate dehydrogenase (GAPDH) levels in left ventricle (LV) and right ventricle $(\mathrm{RV})$ of rats with altered thyroid status. nT - euthyroid control rats $(n=6)$, nTo $-n T$ rats treated with omega- 3 fatty acids (omega-3) $(n=6), d T$ - hypothyroid rats $(n=6)$, dTo $-d T$ rats treated with omega-3 $(n=6)$, hT - hyperthyroid rats $(n=6)$, hTo hT rats treated with omega- $3(n=6)$. Data presented as mean $\pm S D, * P<0.05$ versus $n T$ of $\mathrm{LV}$ or $\mathrm{RV}, \# \mathrm{P}<0.05$ untreated versus treated with omega-3.

\section{Activity of MMP-2 in left ventricle of experimental rats}

Due to limitation of cardiac chamber-related tissue samples only left ventricle was used for determination of MMP-2 activity. Examination of myocardial activity of MMP-2 using gelatin zymography and quantitative analysis revealed differences between experimental groups of rats (Fig. 6AB). There was a significant decrease by $29 \%$ in hypothyroid rat LV. Omega-3 intake did not affect changes induced by altered thyroid status.

\section{Discussion}

Although thyroid hormones (TH) modulate function of numerous proteins in the heart on the genomic and nongenomic level, the data about their effects on myocardial connexins are scarce. $\mathrm{Cx} 43$ is dominant cardiac connexin and expressed in all regions of the heart in characteristic pattern. Cx43 channels ensure rapid spreading of the electrical impulse throughout the heart that is "conditio sinequa none" for coordinated contraction. While disorders in electrical conduction, due to impairment of cellular coupling or uncoupling resulting from changes in $\mathrm{Cx} 43$ expression and/or distribution, promote occurrence of life-threatening arrhythmias (Salameh and Dhein 2005, Tribulova et al. 2015a,b).

In this study we have shown for the first time that thyroid status of rats influences myocardial $\mathrm{Cx} 43$ expression patterns. Moreover, our findings suggest that there are differences in $\mathrm{Cx} 43$ expression responsiveness to altered thyroid status between left versus right ventricle. Accordingly, total $\mathrm{Cx} 43$ protein and its phosphorylated forms were significantly decreased in left ventricle and atria but not in right ventricle and septum of hyperthyroid comparing to euthyroid rat hearts. 
A

PKCE

GAPDH

B

C

D

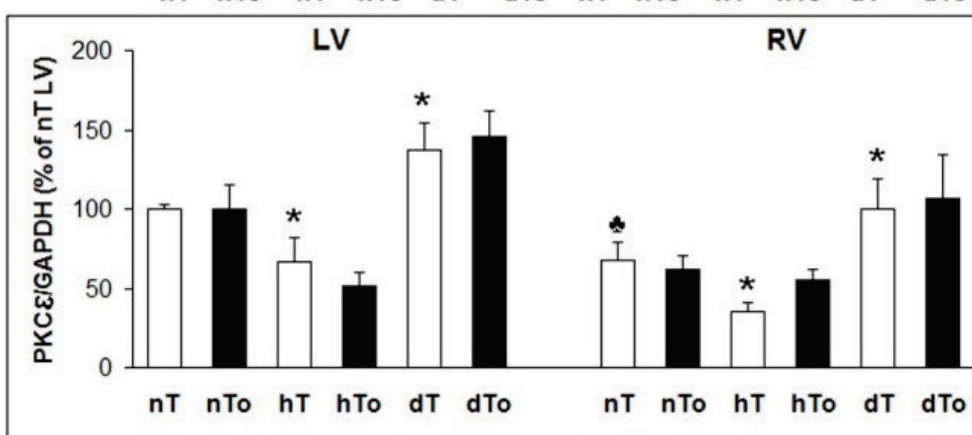

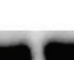
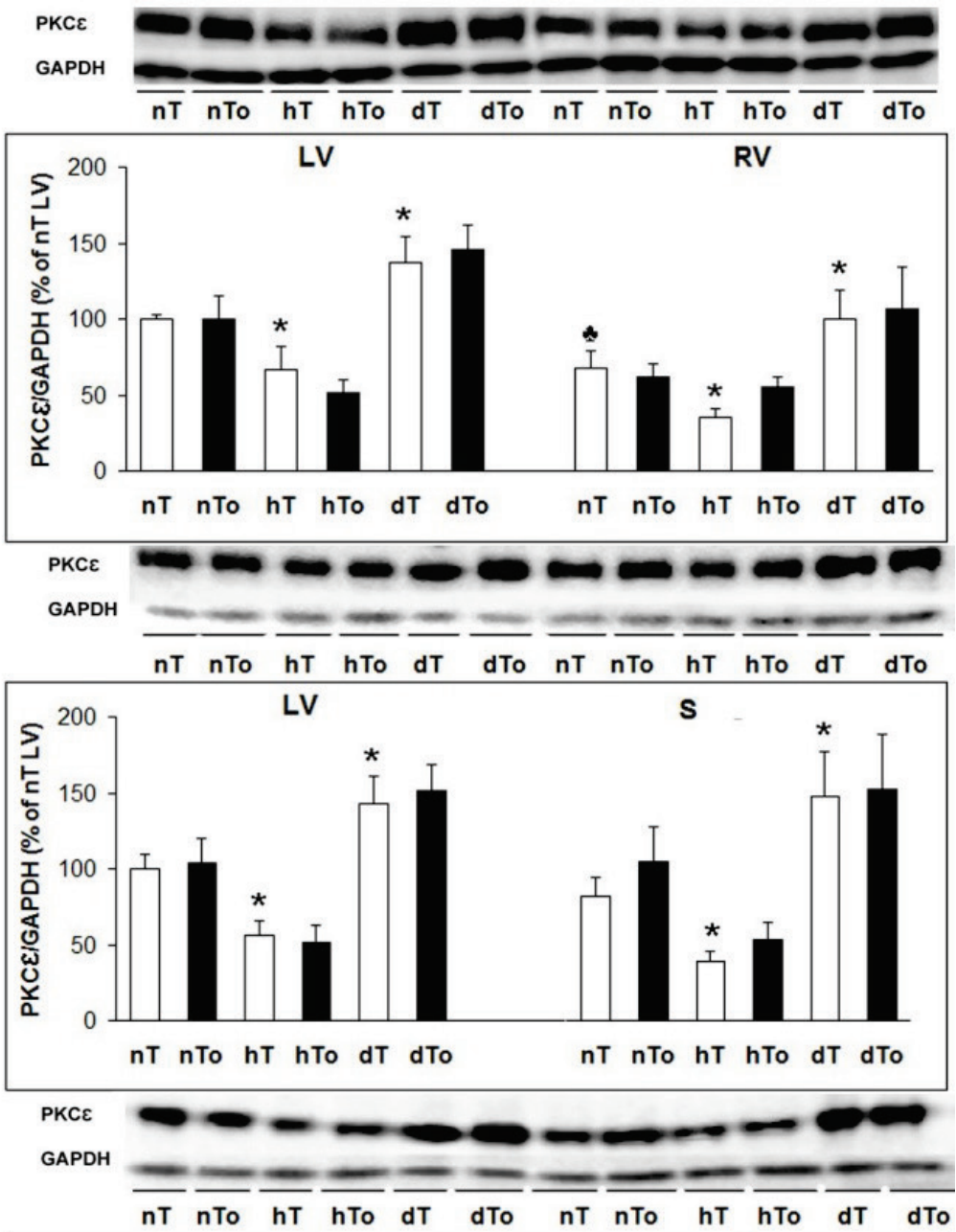

F

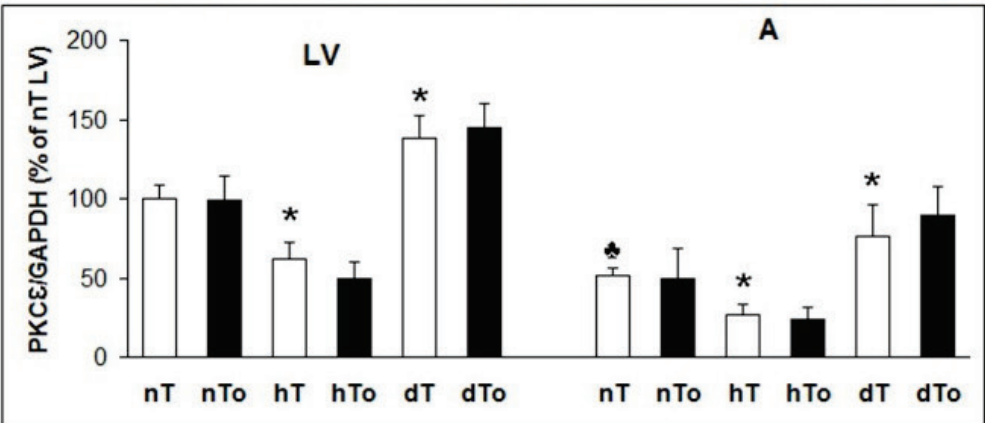

Fig. 4. Myocardial expression of protein kinase C-epsilon (PKCE) protein levels normalized to glyceraldehyde-3-phosphate dehydrogenase (GAPDH) levels in the left ventricle (LV), right ventricle (RV) (AB), septum (S) (CD) and atrium (A) (EF) of rats with altered thyroid status. $\mathrm{nT}$ - euthyroid control rats $(n=6)$, nTo - nT rats treated with omega- 3 fatty acids (omega- 3$)(n=6)$, dT - hypothyroid rats $(n=6)$, dTo - dT rats treated with omega-3 $(n=6), h T-$ hyperthyroid rats $(n=6)$, hTo - hT rats treated with omega-3 $(n=6)$. Data presented as mean $\pm S D, * P<0.05$ versus $n T$ of the respective heart tissue, $\$ \mathrm{P}<0.05 \mathrm{nT}$ of the $L V$ versus $n T$ of the $A$ or RV.
The reason for differential left and right ventricle response is unclear. It perhaps reflects the functional reserve of the left ventricle that did rise very noticeably in thyroxin treated rats unlike right ventricle functional reserve comparing to controls (Cihak et al. 1999). Moreover, the right ventricle exhibits a higher activity of aerobic glycolytic metabolism enabling to respond more efficiently to stress than the left ventricle (WaskovaArnostova et al. 2013). As shown previously, decreased total expression of $\mathrm{Cx} 43$ protein as well as its functional phosphorylated forms in left ventricles of hyperthyroid rats was associated with higher incidence of electrically induced ventricular fibrillation (VF) comparing to euthyroid controls (Lin et al. 2008). This inverse relationship was confirmed in our latest study (data prepared for publication). Moreover, we have found in this study that myocardial $\mathrm{Cx} 43$ mRNA expression was not changed due to administration of thyroid hormones likewise observed previously (Stock and Sies 2000). Data of the latter study support the notion that the thyroid hormone response elements sequence plays an important role in determining the nuclear hormone receptor and coactivator requirements for thyroid receptor action that may be tissue specific. There is no $\mathrm{Cx} 43$ gene responsiveness to thyroid hormone receptor in adult rat heart. 
A

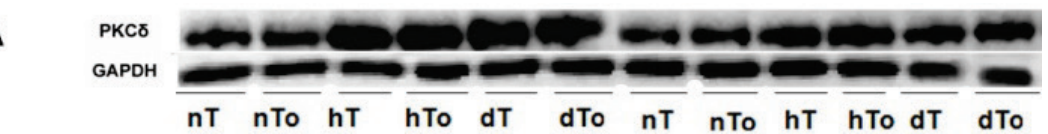

B

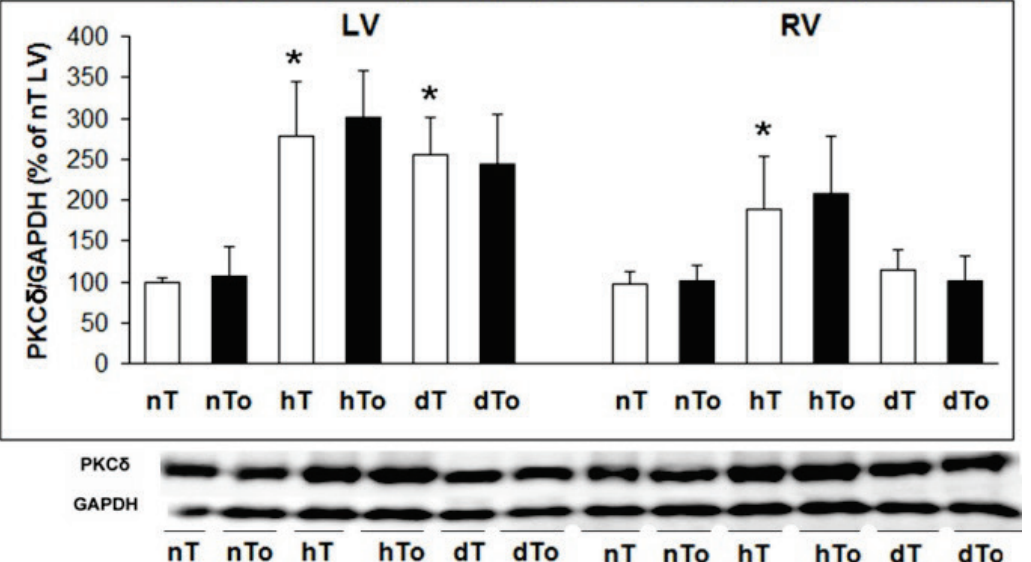

D

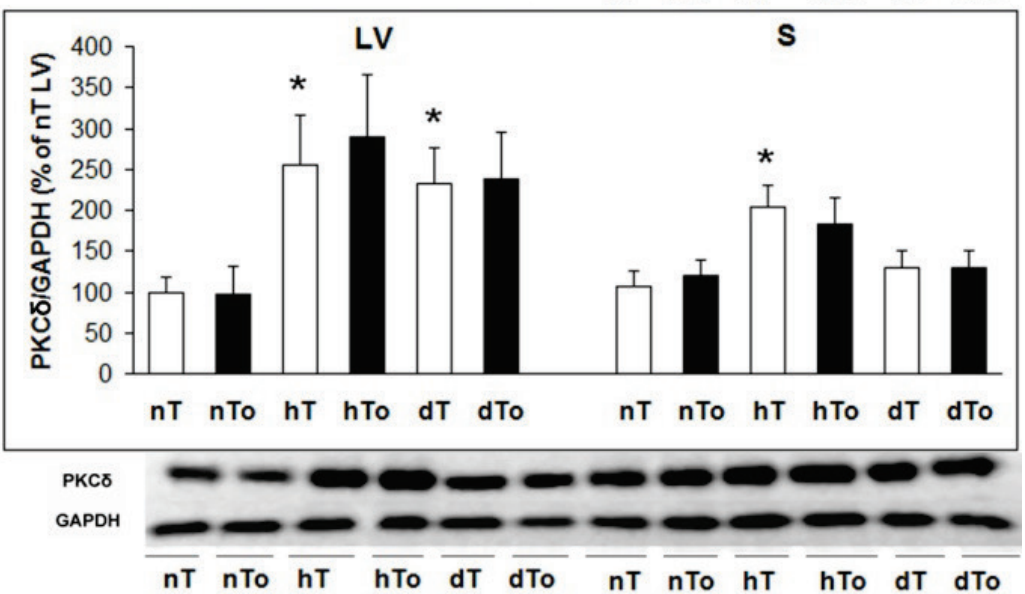

$\mathbf{F}$

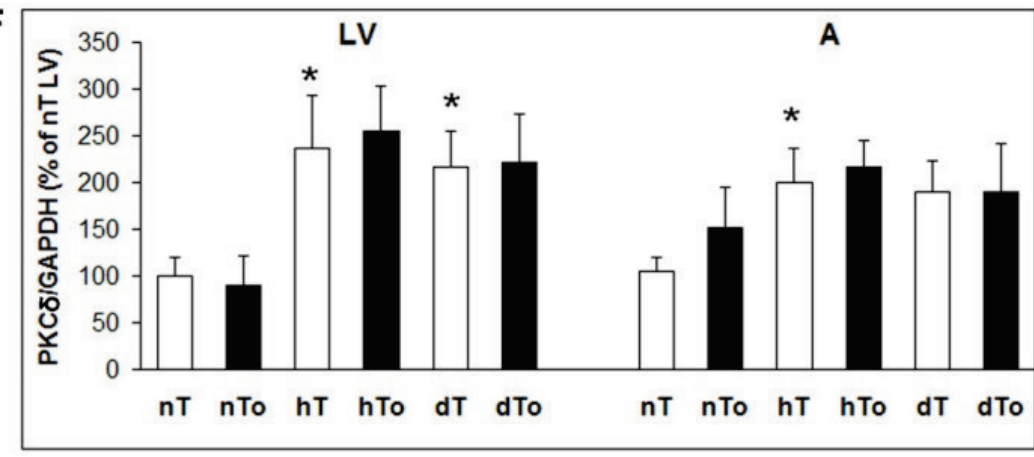

Fig. 5. Myocardial expression of protein kinase C-delta (PKCD) protein levels normalized to glyceraldehyde-3-phosphate dehydrogenase (GAPDH) levels in the left ventricle (LV), right ventricle (RV) (AB), septum (S) (CD) and atrium (A) (EF) of rats with altered thyroid status. nT - euthyroid control rats $(n=6), n T o-n T$ rats treated with omega-3 fatty acids (omega- 3$)(n=6)$, dT hypothyroid rats $(n=6)$, dTo $-d T$ rats treated with omega-3 $(n=6), h T$ - hyperthyroid rats $(n=6)$, hTo $-h T$ rats treated with omega-3 $(n=6)$. Data presented as mean $\pm S D$, $* \mathrm{P}<0.05$ versus $\mathrm{nT}$ of the respective heart tissue.
In the context of reduced $\mathrm{Cx} 43$ proteins it may be assumed that in the heart thyroid hormones modulate factors acting on posttranslational levels. These factors might be related to the oxidative stress that is known to enhance Cx43 degradation (Xia et al. 2006, Tribulova et al. 2015a). Reduced expression of atrial Cx43 protein and/or its functional phosphorylated forms in hyperthyroid rats was also shown previously (Mitasíková et al. 2009). It may at least explain increased propensity of hyperthyroid human heart to atrial fibrillation (Sousa et al. 2015). This view is supported by our unpublished findings showing (Fig. 7) that hyperthyroid rat heart is much prone to develop atrial fibrillation upon burst stimulation comparing to euthyroid animals. Likewise, it was published by others (Zhang et al. 2013). Atrial Cx43 mRNA expression was not altered by thyroid hormones in mice (Almeida et al. 2009). It favours posttranslational modification of $\mathrm{Cx} 43$ protein levels in atria as well. Dealing with cardiac arrhythmia susceptibility it should be noted the salutary effects (Bennet-Guerrero et al. 1996, Zhang et al. 2014) of thyroid hormones administration in condition with their reduced circulating levels such as open heart surgery or post-myocardial infarction. 


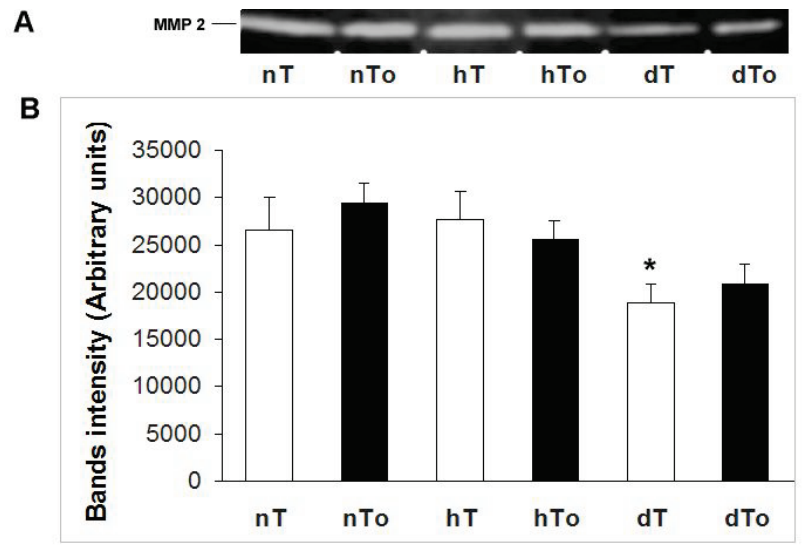

Fig. 6. MMP2 zymography (A) and quantitative analysis of MMP-2 activity (B) in left ventricle (LV) of rats with altered thyroid status. $\mathrm{nT}-$ euthyroid control rats $(n=6), \mathrm{nTo}-\mathrm{nT}$ rats treated with omega-3 fatty acids (omega-3) $(n=6)$, dT - hypothyroid rats $(n=6)$, dTo - dT rats treated with omega-3 $(n=6)$, hT - hyperthyroid rats $(n=6)$, hTo - hT rats treated with omega-3 $(n=6)$. Data presented as mean $\pm S D, * P<0.05$ versus $\mathrm{nT}$.
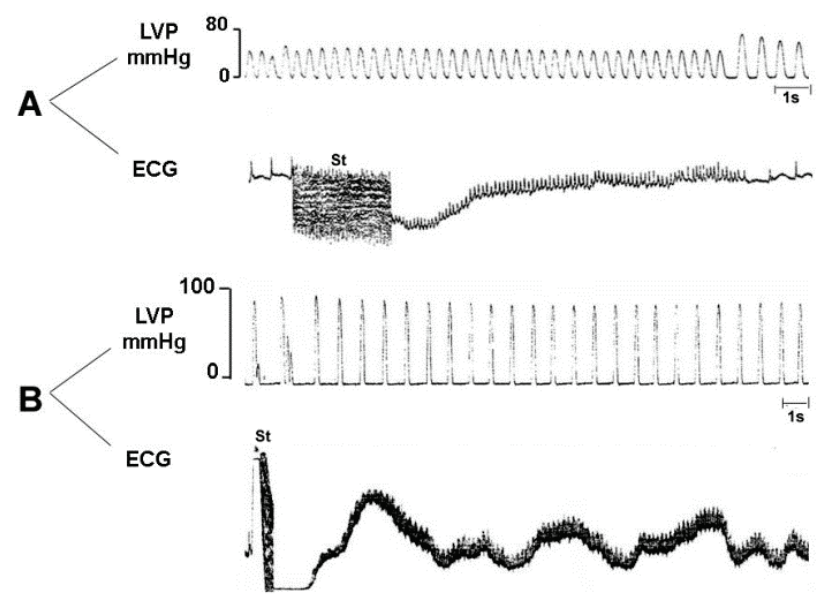

Fig. 7. Electrocardiogram of right atria (ECG) and left ventricular pressure (LVP) registered in isolated perfused rat heart subjected to burst stimulation (St) for examining susceptibility of the heart to atrial fibrillation. Prolonged atrial fibrillo-flutter was easily induced in hyperthyroid rat heart (B), while euthyroid rat heart exhibited only transient atrial tachycardia (A) in response to repetitive electrical stimulation (St).

Available data suggest that the effects of thyroid hormones can be different depending on the conditions, dose and duration of administration. In contrast with the adult rat heart, $\mathrm{Cx} 43$ protein expression was enhanced in cultured neonatal cardiomyocytes exposed to triiodo-1thyronine (Tribulova et al. 2004b), while there was no significant change in response to L-thyroxin in aged rat hearts (Tribulova et al. 2005). These data suggest agerelated differences in heart tissue $\mathrm{Cx} 43$ protein levels in response to thyroid hormones treatment. In parallel, young thyroid treated rats were much susceptible to VF comparing to the old ones (Tribulova et al. 2004a). Age-related cardiac alterations might reflect agedependent differences in the levels of thyroid hormones.

The effect of thyroid hormone deficiency on the heart is much less explored in both, experimental and clinical settings, when comparing to hyperthyroid state. Nevertheless, decline of plasma thyroid hormones was registered in patients with systemic and cardiovascular diseases as well as with ageing and failing heart (Gao et al. 2016, Heckle et al. 2016, Mancini et al. 2016). In contrast to hyperthyroid rats, the protein expression of Cx43 was significantly increased in all examined regions of the hypothyroid rat heart. It was accompanied by increase of functional phosphorylated forms of $\mathrm{Cx} 43$. Data about cardiac $\mathrm{Cx} 43$ in overt hypothyroidism are scarce. However, increased myocardial Cx43 expression was reported in diabetic rats (Lin et al. 2008) that exhibit reduced levels of thyroid hormones (Ferrer et al. 2006). It has also been suggested that hypothyroid state in diabetic rats provides protection from arrhythmias since this protection was abolished by treatment with triiodo-1thyronine (Zhang et al. 2002, Lin et al. 2008). It appears that over-expression of myocardial $\mathrm{Cx} 43$ in hypothyroid rats may underlie decreased vulnerability to inducible VF as previously reported (Bacova et al. 2013). Different to our results, atrial $\mathrm{Cx} 43$ density was not affected in thyroidectomised rat model as assayed by semiquantitative immunohistochemistry (Zhang et al. 2013).

What are possible functional consequences of our key findings? We demonstrated suppression of $\mathrm{Cx} 43$ and PKCE mediated signaling in hyperthyroid while enhancement in hypothyroid rat left ventricle and atria. Taking into account available data (Jeyaraman et al. 2012, Kwak and Jongsma 1996) and our previous study (Lin et al. 2006, 2008) we hypothesize that hyperphosphorylation of $\mathrm{Cx} 43$ in hypothyroid state (likewise in diabetes) may decrease conduction velocity rendering the heart more electrically stable and less vulnerable to malignant arrhythmias. In contrast, increase of conduction velocity in hyperthyroid rats linked with reduced $\mathrm{PKC} \varepsilon$ expression and $\mathrm{Cx} 43$ phosphorylation resulted in higher vulnerability to fatal arrhythmias. It appears that $\mathrm{Cx} 43$ related increase of myocardial conduction velocity might be proarrhythmic while decrease in conduction might be antiarrhythmic at least in some conditions.

Six weeks-lasting omega-3 supplementation of hyper- or hypothyroid rats did not affect changes in 
cardiac Cx43 expression induced by altered thyroid status. Likewise, omega-3 did not significantly affect the changes in lipid metabolism or biometric parameters of these rats (Rauchova et al. 2013). Certainly, the measurements of omega-3 levels in plasma and/or heart tissue of supplemented rats could help to elucidate whether we used sufficient dosing. Of note, all groups of omega-3 treated rats showed clear tendency to enhance circulating thyroid hormones (Table 1). It is needed to pay more attention in further research.

Furthermore, our findings suggest that prolonged hyperthyroidism or hypothyroidism modulate myocardial PKC signaling in all regions of the heart. This pathway is known to play an important role in myocardial remodeling and cardiomyocyte survival in pathophysiological conditions (Palaniyandi et al. 2009). PKC $\varepsilon$ and PKC $\delta$ are abundant PKC isozymes in the adult heart (Duquesnes et al. 2011) and exhibit different effects, i.e. $\mathrm{PKC} \varepsilon$ is mostly protective and $\mathrm{PKC} \delta$ rather detrimental. Activation of PKCE promotes myocardial resistance to injury during oxidative stress. $\mathrm{PKC} \delta$ is pro-apoptotic and pro-fibrotic, however, activation of PKC $\delta$ signaling by mild oxidative stress can be protective in the setting of ischemia. Recent studies suggest that the regulation of cellular viability during pathology might be mediated by the ratio of these isozymes. It should be noted that our study demonstrates changes in the cardiac PKC expression and not their enzyme activities. The latter would be certainly helping in better elucidation the role of cardiac PKC signaling in altered thyroid status.

We showed for the first time that myocardial expression of $\mathrm{PKC} \varepsilon$ in euthyroid rats is highest in left ventricle versus other examined regions. Comparing to euthyroid rat hearts there was a significant decrease of PKCE expression in left and right ventricle (Rybin and Steinbeg 1966), septum as well as in atrium of hyperthyroid but increase in hyperthyroid rat hearts. PKCE isoenzyme selective cardioprotective role might be in part attributed to the phosphorylation of $\mathrm{Cx} 43$, at serine 368, that results in the modulation of intercellular Cx43 channel's function (Lin et al. 2008, Bacova et al. 2013, Radosinska et al. 2013). This view is supported by the findings showing enhanced Cx43 phosphorylated forms in hypothyroid while suppressed in hyperthyroid rat hearts. Based on available data (Rybin et al. 1996, Shimoni 1999, Watson and Gold 1997) and our comprehensive findings we hypothesize that modulation of PKCE pathway by thyroid hormones can affect electrical properties of the heart and arrhythmogenicity via alterations of function of $\mathrm{Cx} 43$ channels as well as ion transport systems. Activation of PKCE signaling in condition of thyroid hormone deficiency may confer protection from arrhythmias most likely due to enhancing of electrical stability of the heart (by decreasing its excitability and conduction velocity). In turn, suppression of PKC $\varepsilon$ pathway by excess of circulating thyroid hormones renders the heart more vulnerable to arrhythmias due to electrical instability resulting from increased excitability and conduction velocity.

In contrary to $\mathrm{PKC} \varepsilon$ there were no regional differences in $\mathrm{PKC} \delta$ expression in euthyroid rat hearts. However, unlike to $\mathrm{PKC} \varepsilon$, the expression of $\mathrm{PKC} \delta$ was markedly increased in ventricles, atrium and septum of hyperthyroid rats as well as in the left ventricle of hypothyroid rats. These findings suggest distinct isoform specific modulation of PKC signaling by thyroid hormones and differences in responsiveness among cardiac compartments. Considering the active role of $\mathrm{PKC} \delta$ in apoptosis our results suggest that this process is enhanced by excess of thyroid hormones. This fact points out that cardiac cells hypertrophy induced by thyroid hormones might be counterbalanced by enhanced apoptosis to fight heart dysfunction and failure. There was no effect of omega-3 supplementation on PKC signaling in altered thyroid status.

Among factors that may affect myocardial arrhythmogenicity are MMPs via their impact on cardiac fibrosis, which impairs $\mathrm{Cx} 43$ channels mediated intercellular coupling. MMPs play central role in development and progression of dysfunctional cardiac remodeling (Nagase et al. 2006) after injury or during pathophysiological conditions (Bartekova et al. 2015). Our results focusing solely on the left ventricle showed that the activity of MMP-2 in hyperthyroid rats is not changed but decreased in hypothyroid animals. It may indicate disorders in extracellular matrix homeostasis that could promote fibrotic process. MMP-2 is synthesized by both, cardiac myocytes and fibroblasts. MMP-2 degrades major components of myocardial extracellular matrix including $\mathrm{I}-\mathrm{V}$ types of collagen, gelatins, laminin, fibronectin and elastin. Hence chronic activation of MMP-2 may deteriorate myocardial structural architecture. Moreover, MMP-2 works not only as a proteolytic enzyme but also as a negative regulator of mitochondrial function during the superimposed oxidative stress (Zhou et al. 2007). On the other hand, activation of MMPs may attenuate accumulation of collagen and subsequent fibrosis of the heart tissue in 
various pathological events. Increased MMP-2 levels were associated with lower fibrosis (Munich et al. 2016). It is not known whether altered thyroid status affects MMPs. Our results showed that activity of MMP-2 in the left ventricle of hyperthyroid rats is not changed but decreased in hypothyroid animals. It indicates disorders in extracellular matrix homeostasis that may promote fibrotic process. However, further more complex analysis is needed to elucidate this issue.

\section{Conclusions}

Our findings point out distinct thyroid status and cardiac chamber related myocardial connexin-43 responsiveness. There is down-regulation of cardiac $\mathrm{Cx} 43$ in atria and left while not right heart ventricle of hyperthyroid and up-regulation of $\mathrm{Cx} 43$ in all heart regions of hypothyroid rats. In parallel, PKCE pathway is suppressed by thyroid hormones but enhanced in hypothyroid status. PKC $\delta$ signaling is activated in both pathological conditions. Short-lasting omega-3 fatty acids supplementation did not significantly affect examined parameters in the heart of rats with altered thyroid status.

\section{Conflict of Interest}

There is no conflict of interest.

\section{Acknowledgements}

The authors thank Mrs K. Bohunová and K. Kopecká from the Institute of Physiology of the Czech Academy of Sciences, Prague for their excellent technical assistance. This work was supported by grants: VEGA 2/0167/15, 2/0076/16, APVV 0348/12, SKS, GACR 305/09/1228, 304/12/0259 and GAUK 628412.

\section{References}

ALMEIDA NA, CORDEIRO A, MACHADO DS, SOUZA LL, ORTIGA-CARVALHO TM, CAMPOS-DECARVALHO AC, WONDISFORD FE, PAZOS-MOURA CC: Connexin40 messenger ribonucleic acid is positively regulated by thyroid hormone $(\mathrm{TH})$ acting in cardiac atria via the TH receptor. Endocrinology $\mathbf{1 5 0}$ : 546-554, 2009.

BAČOVÁ B, RADOŠINSKÁ J, VICZENCZOVÁ C, KNEZL V, DOSENKO V, BEŇOVA T, NAVAROVÁ J, GONÇALVESOVÁ E, VAN ROOYEN J, WEISMANN P, SLEZÁK J, TRIBULOVÁ N: Up-regulation of myocardial connexin-43 in spontaneously hypertensive rats fed red palm oil is most likely implicated in its anti-arrhythmic effects. Can J Physiol Pharmacol 90: 1235-1245, 2012.

BAČOVÁ B, VICZENCZOVÁ C, ŽURMANOVÁ J, KAŠPAROVÁ D, KNEZL V, RADOŠINSKÁ J, BEŇOVÁ T, PAVELKA S, SOUKUP T, TRIBULOVÁ N: Susceptibility of rats with altered thyroid status to malignant arrhythmias is primarily related to myocardial levels of connexin-43 and can be partially ameliorated by supplementation with red palm oil. Exp Clin Cardiol 18: 41-46, 2013.

BARANCIK M, BOHACOVA V, GIBALOVA L, SEDLAK J, SULOVA Z, BREIER A: Potentiation of anticancer drugs: effects of pentoxifylline on neoplastic cells. Int J Mol Sci 13: 369-382, 2012.

BARTEKOVÁ M, ŠIMONČÍKOVÁ P, FOGARASSYOVÁ M, IVANOVÁ M, OKRUHLICOVÁ L, TRIBULOVÁ N, DOVINOVÁ I, BARANČÍK M: Quercetin improves postischemic recovery of heart function in doxorubicintreated rats and prevents doxorubicin-induced matrix metalloproteinase-2 activation and apoptosis induction. Int J Mol Sci 16: 8168-8185, 2015.

BENNETT-GUERRERO E, JIMENEZ JL, WHITE WD, D'AMICO EB, BALDWIN BI, SCHWINN DA: Cardiovascular effects of intravenous triiodothyronine in patients undergoing coronary artery bypass graft surgery. A randomized, double-blind, placebo-controlled trial. Duke T3 study group. JAMA 275: 687-692, 1996.

CIHÁK R, KOLÁR F, PELOUCH V, PROCHÁZKA J, OSTÁDAL B, WIDIMSKÝ J: Functional changes in the right and left ventricle during development of cardiac hypertrophy and after its regression. Cardiovasc Res 26: 845-850, 1992.

DUQUESNES N, LEZOUALC'H F, CROZATIER B: PKC-delta and PKC-epsilon: foes of the same family or strangers? J Mol Cell Cardiol 51: 665-673, 2011. 
FERRER T, GALLEGO M, MADRIGAL-QUINÓNEZ R, TORRES-JÁCOME J, NAVARRO-POLANCO R, CÁSIS O, SÁNCHEZ-CHAPULA: DITPA restores the repolarizing potassium currents Itof and Iss in cardiac ventricular myocytes of diabetic rats. Life Sci 79: 883-889, 2006.

GAO LL, ZHANG MM, ZHANG LP, YANG SL, YAO KJ, SONG YL: A rabbit pulmonary vein myocyte isolation method based on simultaneous heart and pulmonary vein perfusion. Sheng Li Xue Bao 68: 50-56, 2016.

HECKLE MR, FLATT DM, SUN Y, MANCARELLA S, MARION TN, GERLING IC, WEBER KT: Atrophied cardiomyocytes and their potential for rescue and recovery of ventricular function. Heart Fail Rev 21: 191-198, 2016.

IORDANIDOU A, HADZOPOULOU-CLADARAS M, LAZOU A: Non-genomic effects of thyroid hormone in adult cardiac myocytes: relevance to gene expression and cell growth. Mol Cell Biochem 340: 291-300, 2010.

JEYARAMAN MM, SRISAKULDEE W, NICKEL BE, KARDAMI E: Connexin43 phosphorylation and cytoprotection in the heart. Biochim Biophys Acta 1818: 2009-2013, 2012.

KWAK BR, JONGSMA HJ: Regulation of cardiac gap junction channel permeability and conductance by several phosphorylating conditions. Mol Cell Biochem 157: 93-99, 1996.

LIN H, OGAWA K, IMANAGA I, TRIBULOVA N: Remodeling of connexin 43 in the diabetic rat heart. Mol Cell Biochem 290: 69-78, 2006.

LIN H, MITASIKOVA M, DLUGOSOVA K, OKRUHLICOVA L, IMANAGA I, OGAWA K, WEISMANN P, TRIBULOVA N: Thyroid hormones suppress epsilon-PKC signalling, down-regulate connexin-43 and increase lethal arrhythmia susceptibility in non-diabetic and diabetic rat hearts. $J$ Physiol Pharmacol 59: 271-285, 2008.

MANCINI A, DI SEGNI C, RAIMONDO S, OLIVIERI G, SILVESTRINI A, MEUCCI E, CURRÒ D: Thyroid hormones, oxidative stress, and inflammation. Mediators Inflamm 2016: 6757154, 2016.

MITASÍKOVÁ M, LIN H, SOUKUP T, IMANAGA I, TRIBULOVÁ N: Diabetes and thyroid hormones affect connexin-43 and PKC-epsilon expression in rat heart atria. Physiol Res 58: 211-217, 2009.

MÜNCH J, AVANESOV M, BANNAS P, SÄRING D, KRÄMER E, MEARINI G, CARRIER L, SULING A, LUND G, PATTEN M: Serum matrix metalloproteinases as quantitative biomarkers for myocardial fibrosis and sudden cardiac death risk stratification in patients with hypertrophic cardiomyopathy. $J$ Card Fail in press 2016.

NAGASE H, VISSE R, MURPHY G: Structure and function of matrix metalloproteinases and TIMPs. Cardiovasc Res 69: 562-573, 2006.

PALANIYANDI SS, SUN L, FERREIRA JC, MOCHLY-ROSEN D: Protein kinase C in heart failure: a therapeutic target? Cardiovasc Res 82: 229-239, 2009.

PANTOS C, MOUROUZIS I, SARANTEAS T, BROZOU V, GALANOPOULOS G, KOSTOPANAGIOTOU G, COKKINOS DV: Acute T3 treatment protects the heart against ischemia-reperfusion injury via TR $\alpha 1$ receptor. Mol Cell Biochem 353: 235-241, 2011.

PINGITORE A, NICOLINI G, KUSMIC C, IERVASI G, GRIGOLINI P, FORINI F: Cardioprotection and thyroid hormones. Heart Fail Rev 21: 391-399, 2016.

PORTMAN MA: Thyroid hormone regulation of heart metabolism. Thyroid 18: 217-225, 2008.

PURTELL K, ROEPKE TK, ABBOTT GW: Cardiac arrhythmia and thyroid dysfunction: a novel genetic link. Int $J$ Biochem Cell Biol 42: 1767-1770, 2010.

RADOSINSKA J, BACOVA B, KNEZL V, BENOVA T, ZURMANOVA J, SOUKUP T, ARNOSTOVA P, SLEZAK J, GONÇALVESOVA E, TRIBULOVA N: Dietary omega-3 fatty acids attenuate myocardial arrhythmogenic factors and propensity of the heart to lethal arrhythmias in a rodent model of human essential hypertension. J Hypertens 31: 1876-1885, 2013.

RAJAGOPALAN V, ZHANG Y, OJAMAA K, CHEN YF, PINGITORE A, POL CJ, SAUNDERS D, BALASUBRAMANIAN K, TOWNER RA, GERDES AM: Safe oral triiodo-l-thyronine therapy protects from post-infarct cardiac dysfunction and arrhythmias without cardiovascular adverse effects. PLoS One 11: e0151413, 2016. 
RAUCHOVÁ $\mathrm{H}$, VOKURKOVÁ $\mathrm{M}$, PAVELKA $\mathrm{S}$, BEHULIAK $\mathrm{M}$, TRIBULOVÁ N, SOUKUP T: N-3 polyunsaturated fatty acids supplementation does not affect changes of lipid metabolism induced in rats by altered thyroid status. Horm Metab Res 45: 507-512, 2013.

RYBIN V, STEINBERG SF: Thyroid hormone represses protein kinase C isoform expression and activity in rat cardiac myocytes. Circ Res 79: 388-398, 1996.

SALAMEH A, DHEIN S: Pharmacology of gap junctions. New pharmacological targets for treatment of arrhythmia, seizure and cancer? Biochim Biophys Acta 1719: 36-58, 2005.

SHIMONI Y: Protein kinase $\mathrm{C}$ regulation of $\mathrm{K}+$ currents in rat ventricular myocytes and its modification by hormonal status. J Physiol 520: 439-449, 1999.

SOUKUP T: Effects of long-term thyroid hormone level alteration, n-3 poly-unsaturated fatty acid supplementation and statin administration in rats. Physiol Res 63: 119-131, 2014.

SOUZA LL, CORDEIRO A, OLIVEIRA LS, DE PAULA GS, FAUSTINO LC, ORTIGA-CARVALHO TM, OLIVEIRA KJ, PAZOS-MOURA CC: Thyroid hormone contributes to the hypolipidemic effect of polyunsaturated fatty acids from fish oil: in vivo evidence for cross talking mechanisms. $J$ Endocrinol 211: 65-72, 2011.

STOCK A, SIES H: Thyroid hormone receptors bind to an element in the connexin43 promoter. Biol Chem 381: 973-979, 2000.

TRIBULOVA N, KNEZL V, OKRUHLICOVA L: L-thyroxine increases susceptibility of adult rats to low K+-induced ventricular fibrillation, and sinus rhythm restoration in old rats. Exp Physiol 89: 629-636, 2004 a.

TRIBULOVA N, SHNEYVAYS V, MAMEDOVA LK, MOSHEL S, ZINMAN T, SHAINBERG A, MANOACH M, WEISMANN P, KOSTIN S: Enhanced connexin-43 and alpha-sarcomeric actin expression in cultured heart myocytes exposed to triiodo-L-thyronine. J Mol Histol 35: 463-470, $2004 \mathrm{~b}$.

TRIBULOVÁ N, DUPONT E, SOUKUP T, OKRUHLICOVÁ L, SEVERS NJ: Sex differences in connexin-43 expression in left ventricles of aging rats. Physiol Res 54: 705-708, 2005.

TRIBULOVA N, KNEZL V, SHAINBERG A, SEKI S, SOUKUP T: Thyroid hormones and cardiac arrhythmias. Vascul Pharmacol 52: 102-112, 2010.

TRIBULOVA N, SZEIFFOVA BACOVA B, BENOVA T, VICZENCZOVA C: Can we protect from malignant arrhythmias by modulation of cardiac cell-to-cell coupling? J Electrocardiol 48: 434-440, $2015 \mathrm{a}$.

TRIBULOVA N, EGAN BENOVA T, SZEIFFOVA BACOVA B, VICZENCZOVA C, BARANCIK M: New aspects of pathogenesis of atrial fibrillation: remodelling of intercalated discs. J Physiol Pharmacol 66: 625-634, 2015b.

WASKOVA-ARNOSTOVA P, ELSNICOVA B, KASPAROVA D, SEBESTA O, NOVOTNY J, NECKAR J, KOLAR F, ZURMANOVA J: Right-to-left ventricular differences in the expression of mitochondrial hexokinase and phosphorylation of Akt. Cell Physiol Biochem 31: 66-79, 2013.

WATSON CL, GOLD MR: Modulation of $\mathrm{Na}+$ current inactivation by stimulation of protein kinase C in cardiac cells. Circ Res 81: 380-386, 1997.

XIA HJ, DAI DZ, DAI Y: Up-regulated inflammatory factors endothelin, NFkappaB, TNFalpha and iNOS involved in exaggerated cardiac arrhythmias in 1-thyroxine-induced cardiomyopathy are suppressed by darusentan in rats. Life Sci 79: 1812-1819, 2006.

ZHANG L, PARRATT JR, BEASTALL GH, PYNE NJ, FURMAN BL: Streptozotocin diabetes protects against arrhythmias in rat isolated hearts: role of hypothyroidism. Eur J Pharmacol 435: 269-276, 2002.

ZHANG Y, DEDKOV EI, TEPLITSKY D, WELTMAN NY, POL CJ, RAJAGOPALAN V, LEE B, GERDES AM: Both hypothyroidism and hyperthyroidism increase atrial fibrillation inducibility in rats. Circ Arrhythm Electrophysiol 6: 952-959, 2013.

ZHANG Y, DEDKOV EI, LEE B 3RD, LI Y, PUN K, GERDES AM: Thyroid hormone replacement therapy attenuates atrial remodeling and reduces atrial fibrillation inducibility in a rat myocardial infarction-heart failure model. J Card Fail 20: 1012-1019, 2014.

ZHOU HZ, MA X, GRAY MO, ZHU BQ, NGUYEN AP, BAKER AJ, SIMONIS U, CECCHINI G, LOVETT DH, KARLINER JS: Transgenic MMP-2 expression induces latent cardiac mitochondrial dysfunction. Biochem Biophys Res Commun 358: 189-195, 2007. 
ZINMAN T, SHNEYVAYS V, TRIBULOVA N, MANOACH M, SHAINBERG A: Acute, nongenomic effect of thyroid hormones in preventing calcium overload in newborn rat cardiocytes. J Cell Physiol 207: 220-231, 2006. 